\title{
Phosphorus Solubilization by Thermotolerant Bacillus subtilis Isolated from Cow Dung Microflora
}

\author{
Manas R. Swain • K. Laxminarayana • \\ Ramesh C. Ray
}

Received: 28 January 2012/Accepted: 2 May 2012/Published online: 1 June 2012

(C) NAAS (National Academy of Agricultural Sciences) 2012

\begin{abstract}
Soil inoculation with phosphate-solubilizing bacteria is known to improve solubilization of fixed soil phosphorus $(\mathrm{P})$. Cow dung $(\mathrm{CD})$ is normally used as an organic manure for enhancing soil fertility in tropical agriculture. Thermotolerant $\left(<50{ }^{\circ} \mathrm{C}\right)$ Bacillus subtilis strains isolated from $\mathrm{CD}$ solubilized tricalcium phosphate $(\mathrm{CP})$ to available (soluble) phosphate in culture and in autoclaved soil amended with $1 \% \mathrm{CP}$. The solubilization of $\mathrm{CP}$ was associated with the phosphatase activity of the bacterium, particularly acid phosphatase (AcP). Autoclaved soil amended with CD (10\%) showed 25.3 and $12.6 \%$ higher solubilization of $\mathrm{P}$ and AcP activity, respectively, than autoclaved soil inoculated with B. subtilis. Also, B. subtilis inoculation and CD amendment resulted in higher P solubilization and phosphatase activity in both rhizosphere and nonrhizosphere of soil planted with cowpea (Vigna unguiculata L.) than without these two treatments. Similarly, root length, plant height, and plant biomass of cowpea seedlings were higher in bacterium- or CD-treated soil than in untreated soil. These results suggest that these thermotolerant $B$. subtilis strains as bio-inoculant or CD amendment can be successfully employed in tropical agriculture for solubilization of $\mathrm{P}$ and maintaining soil health, being useful in the context of global warming.
\end{abstract}

Keywords Cow dung $\cdot$ Bacillus subtilis $\cdot$ Phosphorus $\cdot$ Tricalcium phosphate $\cdot$ Acid phosphatase $\cdot$ Alkaline phosphatase

\section{Introduction}

Phosphorus $(\mathrm{P})$ is one of the major nutrients limiting plant growth [1]. However, essential plant nutrients such as $\mathrm{P}$ remain insoluble in soil systems [10]. Phosphorus is present in the soil in both inorganic and organic compounds. Microorganisms bring about a number of transformations of soil P, which include: (a) increasing the solubility of inorganic compounds of $\mathrm{P}$, (b) mineralizing organic compounds with release of inorganic phosphate, (c) converting inorganic, available anion (phosphate) into cell components, and (d) oxidation or reduction of organic P compounds [2].

M. R. Swain · K. Laxminarayana · R. C. Ray ( $\bigotimes)$

Central Tuber Crops Research Institute (Regional Centre),

Bhubaneswar 751019, India

e-mail: rc_rayctcri@rediffmail.com
As far as $\mathrm{P}$ availability to plants is concerned, mineral soil $\mathrm{P}$ may be divided into three categories: $\mathrm{P}$ soluble in the soil solution ( $\mathrm{P}$ available to plant uptake), labile $\mathrm{P}$ in the solid phase ( $\mathrm{P}$ ready to solubilize in soil solution), and insoluble (fixed) P in the solid phase [1]. Only a small soil $P$ stock contained in soil solution serves as an immediate source of P for plants. When this pool is depleted, the soil system balance is disturbed and some of the labile $\mathrm{P}$ is released into soil solution. Also, the phosphate concentration in soil solution may continuously change due to phosphate sorption and desorption by both biotic (microorganisms) and abiotic ( $\mathrm{pH}$, temperature, etc.) factors [10]. The dominant process determines the net changes in $\mathrm{P}$ concentration.

Regular, high amounts of mineral P, i.e., calcium hydrogen phosphate and tricalcium phosphate, are added to agricultural soils to achieve high crop yield [10, 12]. Phosphate ions are extremely reactive, and a large portion of applied inorganic $\mathrm{P}$ is converted to insoluble $\mathrm{P}$ through 
immobilization and chelation with metal ligands such as $\mathrm{Ca}^{2+}$ in neutral and alkaline soils, and with $\mathrm{Fe}^{2+}$ and $\mathrm{Al}^{3+}$ in acidic soils, becoming unavailable for plant uptake [4]. One of the options for transforming these insoluble forms of $\mathrm{P}$ into a (soluble) form available to plants is by solubilization by microorganisms possessing acid and alkaline phosphatase activity [3, 17]. Strains from the genera Alcaligenes, Burkholderia, Enterobactor, Pseudomonas, and Bacillus (bacteria) and Aspergillus, Fusarium, Penicillium, and Rhizopus (fungi) are among the most powerful phosphate-solubilizing microorganisms isolated from soil and rhizosphere [6, 18].

In our earlier studies, Bacillus subtilis strains were found to be predominant bacteria isolated from cow dung (CD). These strains are thermotolerant $\left(<50{ }^{\circ} \mathrm{C}\right)$, and their role in biotransformations of minerals such as $\mathrm{P}$ and sulfur in soil have been demonstrated in vitro [22]. The present investigation was carried out to study $\mathrm{P}$ solubilization by $B$. subtilis in culture medium and in autoclaved soil inoculated with $B$. subtilis or amended with $\mathrm{CD}$, and study the growth of cow pea (Vigna unguiculata L.) in a soil system treated with $B$. subtilis or $\mathrm{CD}$.

\section{Materials and Methods}

\section{B. subtilis Strains}

Five Bacillus isolates (CM1, CM2, CM3, CM4, and CM5) were isolated from $\mathrm{CD}$ [22]. These isolates were confirmed as B. subtilis strains based on morphological, biochemical, and molecular [16S DNA sequence and random amplification of polymorphic DNA (RAPD) analysis] characteristics and comparison with $B$. subtilis type strain MTCC 441 [22, 23]. The isolates were maintained on nutrient agar slants at $4{ }^{\circ} \mathrm{C}$, and the same were used in the present investigation.

Cow dung (fresh, and 6- and 12-month aged) was collected from lactating cows and brought in sterile polyethylene bags to the Microbiology Laboratory of Regional Centre of Central Tuber Crops Research Institute, Bhubaneswar, Orissa, India. The collected CD was diluted to $10^{2}-10^{6}$ dilutions with sterile distilled water, and $1 \mathrm{ml}$ of each dilution was added on the nutrient agar for enumerating bacteria. Three replicates (Petri plates) were maintained for each dilution and incubated at $30-50{ }^{\circ} \mathrm{C}$ until colonies were observed [22]. The bacterial strains CM1, CM2, CM3, CM4, and CM5 were finally selected because of their thermotolerance $\left(<50{ }^{\circ} \mathrm{C}\right)$, antagonistic activity against plant pathogens such as Fusarium oxysporum and Botryodiplodia theobromae, and other beneficial activities such as sulfur oxidation and indole-3-acetic acid production [23].
P Solubilization

Preliminary studies (qualitative testing) had shown that all five of these strains could solubilize inorganic $\mathrm{P}$ to $\mathrm{PO}_{4}{ }^{3-}$ at ambient $\left(30 \pm 2{ }^{\circ} \mathrm{C}\right)$ to $50{ }^{\circ} \mathrm{C}$ in National Botanical Research Institute's phosphate (NBRIP) growth medium [13]. However, further experiments were conducted only at ambient temperature. To select the most efficient P-solubilizing strain, qualitative estimation of $\mathrm{P}$ solubilization was carried out using modified NBRIP medium in Erlenmeyer flasks $(250 \mathrm{ml})$ in triplicates containing $100 \mathrm{ml}$ medium $\left[(\mathrm{g} / \mathrm{l})\right.$ : glucose, $10.00 ; \mathrm{CP}, 5.00 ; \mathrm{MgCl}_{2}, 5.00$; $\mathrm{MgSO}_{4}, 0.5$; $\left(\mathrm{NH}_{4}\right)_{2} \mathrm{SO}_{4}, 0.1$; bromophenol blue, 0.025] inoculated with $1 \mathrm{ml}\left[2 \times 10^{8}\right.$ colony-forming units (CFU)/ml] of B. subtilis (CM1-CM5). Uninoculated flasks were kept as control. Inoculated and control flasks were incubated at room temperature $\left(30 \pm 2{ }^{\circ} \mathrm{C}\right)$ for $48 \mathrm{~h}$. The decrease in dark-blue color of bromophenol blue due to acidification of the medium (indicating $\mathrm{P}$ solubilization) into light-yellow color [13] was observed visually using a color chart.

For quantitative estimation of $\mathrm{P}$ solubilization, NBRIP medium minus bromophenol blue (to eliminate color interference) was used to determine available (soluble) phosphate. One hundred milliliters of medium taken in 250-ml Erlenmeyer flasks (in triplicates) was inoculated with bacterial (CM1-CM5) culture $\left(2 \times 10^{8} \mathrm{CFU} / \mathrm{ml}\right)$ and incubated for $48 \mathrm{~h}$. After incubation, the culture filtrates (filtered through Whatman no. 42 filter paper) were analyzed for available phosphate, $\mathrm{pH}$, and phosphatase (acid and alkaline) activity. In another experiment, only strain CM1 was used to study the progress of $\mathrm{P}$ solubilization (phosphate availability and phosphatase activity) at 12-h intervals up to $48 \mathrm{~h}$.

\section{Phosphatase Activity in the Soil System}

A neutral sandy loam soil (Entisol, pH 7.2; organic C, 5.6 $\mathrm{g} / \mathrm{kg}$; total N, $0.8 \mathrm{~g} / \mathrm{kg}$; total P, $0.045 \mathrm{~g} / \mathrm{kg}$ ) was used for this study. Soil samples ( $20 \mathrm{~g}$ sieved to particle size of $2 \mathrm{~mm}$ ) taken in 250-ml Erlenmeyer flasks were autoclaved for $1 \mathrm{~h}$ at $121{ }^{\circ} \mathrm{C}$ for three successive days, and on cooling, the soil moisture content was adjusted to $60 \%(\mathrm{v} / \mathrm{w})$ (moisture holding capacity) with sterile, deionized water. The sterilized soil was then amended with CP (1\%) and inoculated with $1 \mathrm{ml}$ bacterial starter culture $\left(2 \times 10^{8} \mathrm{CFU} / \mathrm{ml}\right)$. The flasks were wrapped with aluminum foil, perforated with fine holes to allow gas exchange. Available phosphate, $\mathrm{pH}$, and phosphatase (acid and alkaline) activity were determined at 5-day intervals up to 25 days.

In another experiment, $2 \mathrm{~g} \mathrm{CD}(\mathrm{g} / \mathrm{kg}$ dry weight: organic $\mathrm{C}, 121 \pm 5.60$; total $\mathrm{N}, 11.6 \pm 0.11$; total $\mathrm{P}, 4.9 \pm 2.40$, containing total bacteria $8.0 \times 10^{7} \mathrm{CFU} / \mathrm{g}$, including 
$2 \times 10^{7} \mathrm{CFU} / \mathrm{g}$ of Bacillus spp.; fungi, $4.6 \times 10^{5} \mathrm{CFU} / \mathrm{g}$; actinomycetes, $2 \times 10^{5} \mathrm{CFU} / \mathrm{g}$ ) along with $1 \% \mathrm{CP}$ was added to autoclaved soil sample (1:10 ratio), taken in Erlenmeyer flasks (in triplicate). Autoclaved soil (20 g) (in triplicate) without amendment of $\mathrm{CD}$ but with $1 \% \mathrm{CP}$ served as the control. Moisture content in control and soil plus CD was adjusted to $60 \%$ (moisture holding capacity). Available phosphate, $\mathrm{pH}$, and phosphatase activity of the soil samples $(n=3)$ were determined at 5-day intervals up to 25 days. The control and CD-amended soils $(n=3)$ were analyzed for $\mathrm{pH}$ (soil:water, 1:2) using glass electrode.

Available $\mathrm{P}$ was determined by shaking the soil $(20 \mathrm{~g})$ with $80 \mathrm{ml}$ Olsen's reagent $\left(0.5 \mathrm{M} \mathrm{NaHCO}_{3}, \mathrm{pH} 8.5\right)$ followed by filtration through Whatman no. 42 filter paper, using the aliquots for P estimation [15].

\section{Phosphate Estimation and Phosphatase Assay}

Phosphate concentrations in soil supernatants and bacterial cultures (in triplicate) were determined spectrophotometrically by ascorbic acid method [26]. The absorbance (nm) values of the phosphate concentrations were extrapolated on a standard curve determined by using serially diluted standard $\mathrm{P}\left(\mathrm{KH}_{2} \mathrm{PO}_{4}\right)$ solution. Phosphate was expressed as $\mu \mathrm{g} / \mathrm{ml}$ (in liquid medium) or $\mu \mathrm{g} / \mathrm{g}$ soil (in soil samples).

Phosphatase activity in soil supernatants and bacterial cultures (in triplicate) was determined spectrophotometrically by the method of Tabatabai and Bremner [24]. One unit of phosphatase activity was defined as the amount of enzyme required to release $1 \mu \mathrm{mol} p$-nitrophenol $/ \mathrm{min} / \mathrm{ml}$ from disodium $p$-nitrophenyl phosphate (tetrahydrate) under the assay condition. For soil, units of enzyme activity were calculated as units/g dry soil.

\section{In Vivo Application}

Cow pea (Vigna unguiculata L.) seeds were surface-sterilized with $1 \% \mathrm{NaOCl}$ solution for $10 \mathrm{~min}$ and divided into three sets. In the first set, the seeds were placed in planting holes $(5 \mathrm{~mm}$ each) of presterilized (autoclaved at $121{ }^{\circ} \mathrm{C}$ for $1 \mathrm{~h}$ for three successive days) soil $(1 \mathrm{~kg})$ amended with CP $(1 \%)$ contained in polyethylene bags. Three milliliters of bacterial spore suspensions was applied to the individual polyethylene bags in planting holes. In the second set, seeds were similarly placed in polyethylene bags containing presterilized soil $(1 \mathrm{~kg})$ but amended with $100 \mathrm{~g}$ dry and powdered CD $(=10 \%)$ instead of bacterial inoculum. The third set (control) was maintained by just planting the seeds in presterilized soil but without bacterial inoculum or CD. Two seedlings were allowed to grow in each polyethylene bag. The experiment was laid out in completely randomized block design with four replicates each for control, $\mathrm{CD}$, and B. subtilis-treated soils. Twenty days after seedling emergence, rhizosphere and nonrhizosphere soil samples were collected from all three sets by standard procedure [25] and assayed for phosphate concentration and phosphatase activity. Root length, plant height, and plant biomass were also examined by the standard method as described by Reyes et al. [17].

\section{Statistical Analysis}

Data for phosphatase and available P (Tables 1, 2, 3) were analyzed using one-way analysis of variance (ANOVA). Fisher's least significant difference (LSD) comparison test was applied to compare the mean level difference where ANOVA showed significant variation. The analysis was performed using TMTAT-C (version 2.0; Michigan State University, Michigan, USA).

The changes in $\mathrm{pH}$, phosphatase, and available $\mathrm{P}$ over time (incubation period) in B. subtilis-inoculated Entisol and cow dung-amended Entisol (Figs. 1, 2) were analyzed using one-way repeated-measures ANOVA. Polynomial contrasts were computed to compare with mean difference of $\mathrm{pH}$, phosphatase, and phosphate production at different incubation periods. These statistical methods were performed using SPSS software (for Windows, release 13.0; SPSS Inc., Chicago, IL, USA).

\section{Survival of B. subtilis}

Survival of B. subtilis was determined after each experiment in soil samples. One gram of soil was resuspended in sterile water $(100 \mathrm{ml})$, shaken thoroughly for $30 \mathrm{~min}$, and serially diluted up to $10^{6}$ dilution. Each $1 \mathrm{ml}$ of diluted suspension $\left(10^{5}-10^{8}\right)$ was spread-plated on nutrient agar and incubated for $48 \mathrm{~h}$ in an incubator at $30 \pm 2{ }^{\circ} \mathrm{C}$. Bacterial colonies developed on nutrient agar plates and were counted as $\mathrm{CFU} / \mathrm{g}$ dry soil using a colony counter.

\section{Results and Discussion}

Several studies had showed that inorganic phosphate is solubilized by soil and rhizosphere microorganisms by the production of organic acids and chelating oxo-acids from sugar $[10,14]$. Therefore, most quantitative tests to assay the reactive efficiency of phosphate-solubilizing bacteria are based on lowering of $\mathrm{pH}$ owing to production of organic acids into the surrounding medium [7]. Bromophenol blue is a $\mathrm{pH}$ indicator dye whose color changes from dark blue to faint yellow when $\mathrm{pH}$ drops. Incorporation of bromophenol blue into culture medium has been studied by several workers for qualitative determination of $\mathrm{P}$ solubilization by microorganisms in culture media [7, 13]. Phosphate-solubilizing bacteria can be routinely 
screened by a plate assay method using Pikovskaya agar [16]. Testing of the relative efficiency of isolated strains is carried out by selecting microorganisms that are capable of producing a halo/clear zone on a plate owing to the production of organic acids. However, the reliability of this halo-based technique is very often questioned, as many isolates did not produce any visible halo/zone on agar plates but could solubilize various types of insoluble inorganic phosphates in liquid medium [7]. Using NBRIP medium with bromophenol blue, the five bacterial strains (CM1-CM5) were screened initially by observing the change in color from blue to faint yellow using a color chart; CM1 was found to be the most efficient P-solubilizing strain based on the visual change of blue color to faintish yellow.

For phosphate solubilization, phosphobacteria produce AcP and alkaline phosphatase (AlP) enzymes. Quantitative estimation of $\mathrm{P}$ solubilization and AcP and AlP enzyme activities also confirmed that CM1 was the most efficient strain (Table 1). CM1 produced the highest phosphatase [AcP $(p=0.001, \mathrm{LSD}=3.26)$; AlP $(p=0.001, \mathrm{LSD}=$ 1.96)] activity in NBRIP medium. The rate of $P$ solubilization was associated with decease of the $\mathrm{pH}$ of the growth medium from 6.9 (initial) to $3.5,4.3,4.1,3.8$, and 5.2 (final) for strains CM1, CM2, CM3, CM4, and CM5, respectively. This $\mathrm{pH}$ decrease was possibly due to production of organic acids by $B$. subtilis. There are reports that various P-solubilizing species of Bacillus (i.e., B. licheniformis, B. amyloliquefaciens, B. firmus, etc.) produce a mixture of lactic, oxalic, glycolic, 2-ketoguconic, malonic, and succinic acid [18]. There was a positive significant relationship $(r)$ between $\mathrm{P}$ solubilization ( $\mathrm{P}$ concentration in soil solution after incubation) and phosphatase activity [AcP $(r=0.44, p=0.05)$; AlP $(r=0.89, p=0.01]$ and a negative significant relationship between $\mathrm{P}$ solubilization and $\mathrm{pH}(r=-0.83, p=0.01)$. Further, there was a steady increase in phosphatase production during the 48-h course of study. AcP production was 30.2 units at $12 \mathrm{~h}$, which increased to $45.2,57.2$, and 78.1 units at 24, 36, and $48 \mathrm{~h}$, respectively. Similarly, AlP activity was 37.2, 53.0, 71.2, and 94.6 units at 12, 24, 36, and $48 \mathrm{~h}$, respectively. Available $\mathrm{P}(\mu \mathrm{g} / \mathrm{ml})$ in the medium also increased from $10.0(12 \mathrm{~h})$ to $30.1(48 \mathrm{~h})$ during the corresponding period; simultaneously, a gradual decrease in $\mathrm{pH}$ from $6.1(12 \mathrm{~h})$ to 3.5 (48 h) was observed.

Figure 1 shows the trend of $\mathrm{P}$ solubilization and phosphatase activity in autoclaved soils amended with $1 \% \mathrm{CP}$ ( $0.2 \mathrm{~g} \mathrm{CP} / 20 \mathrm{~g}$ soil) and inoculated with CM1 strain. Oneway repeated-measures ANOVA showed that the concentration of available phosphate increased significantly $\left[F(1.56,3.13)=457.52, p=0.000\right.$, eta $\left.^{2}=0.996\right]$ over the incubation period. The polynomial contrasts confirmed that there was a significant linear trend $[F(1,2)=$ $29,584.00, p=0.000$, eta $\left.{ }^{2}=0.996\right]$, concomitant with a decrease in $\mathrm{pH}$ from 6.9 (initial $\mathrm{pH}$ of soil after autoclaving) to $5.3\left[F(1.20,2.39)=27.13, p=0.023\right.$, eta $^{2}=$ 0.931]. Further, examination of means suggested that the decrease in $\mathrm{pH}$ with increasing incubation period and polynomial contrast confirmed that there was a significant linear trend $\left[F(1,2)=61.85, p=0.016\right.$, eta $\left.{ }^{2}=0.969\right]$ after 25 days (Fig. 1a). The decrease in soil $\mathrm{pH}$ might be due to production of organic acids by $B$. subtilis $\mathrm{CM} 1$. AcP and AlP activity increased from zero (0th day) to 210 and 109 units (20th day), respectively. AcP activity showed significant difference from AlP activity $[F(1.11,2.23)=$ $1,535.72, p=0.000$, eta $\left.^{2}=0.999\right]$ after 25 days of incubation (Fig. 1b). Examination of means suggested that AcP activity increased until the 15th day and decreased thereafter $\left[F(1,2)=23,287.41, p=0.000\right.$, eta $\left.^{2}=0.999\right]$. The increase in phosphatase activity in bacteria-inoculated soil was expected because of the increase in B. subtilis population during the incubation period [19]. In the present study, the B. subtilis population increased in inoculated soil from $1 \times 10^{7} \mathrm{CFU} / \mathrm{g}$ soil (0 days) to $3 \times 10^{7} \mathrm{CFU} / \mathrm{g}$ soil (5 days) to $5-7 \times 10^{7} \mathrm{CFU} / \mathrm{g}$ soil during $10-25$ days of incubation. Autoclaving removes competition and

Table 1 P solubilization and phosphatase production by B. subtilis strains in National Botanical Research Institute's phosphate culture medium after $48 \mathrm{~h}$ of incubation

\begin{tabular}{|c|c|c|c|c|}
\hline \multirow[t]{2}{*}{ Strain } & \multirow[t]{2}{*}{ Available phosphate $(\mu \mathrm{g} / \mathrm{ml})$} & \multicolumn{2}{|c|}{ Phosphatase (units/ml) } & \multirow[t]{2}{*}{ Final medium $\mathrm{pH}$} \\
\hline & & Acid & Alkaline & \\
\hline CM1 & $30.1 \pm 1.2$ & $78.1 \pm 2.8$ & $94.6 \pm 1.0$ & $3.5 \pm 0.1$ \\
\hline CM2 & $25.8 \pm 0.8$ & $62.1 \pm 1.6$ & $68.3 \pm 2.3$ & $4.3 \pm 0.2$ \\
\hline CM3 & $23.8 \pm 1.1$ & $70.2 \pm 2.6$ & $82.3 \pm 1.6$ & $4.1 \pm 0.0$ \\
\hline CM4 & $26.3 \pm 1.5$ & $64.3 \pm 1.2$ & $72.1 \pm 2.0$ & $3.8 \pm 0.1$ \\
\hline CM5 & $20.0 \pm 1.3$ & $68.3 \pm 1.4$ & $90.2 \pm 2.0$ & $5.2 \pm 0.2$ \\
\hline $\operatorname{LSD}(p=0.05)$ & 2.36 & 3.26 & 1.91 & 0.19 \\
\hline
\end{tabular}

$n=3 ; \pm$ standard error 

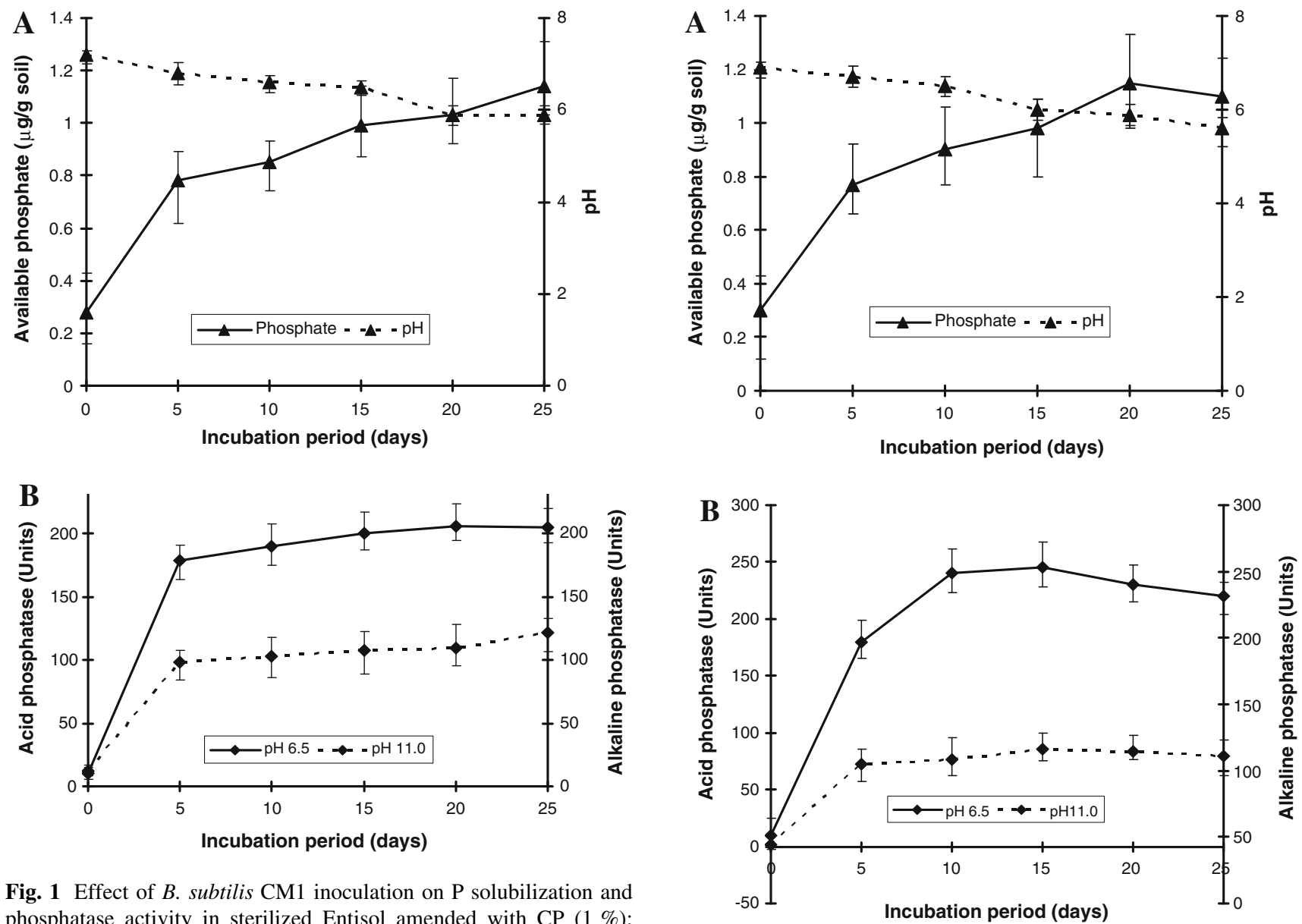

Fig. 1 Effect of B. subtilis CM1 inoculation on P solubilization and phosphatase activity in sterilized Entisol amended with CP (1\%): $\mathbf{a}$ available phosphate and $\mathrm{pH}$, and $\mathbf{b}$ acid phosphatase and alkaline phosphatase

changes the chemical composition of the soil; B. subtilis in the present case could still grow under unnatural conditions. A bacterium that could solubilize CP in autoclaved soil can presumably do so in unsterilized soil. Further, the results of experiments carried out in sterile soils cannot always be extrapolated to natural soil conditions where the inoculant has to face tough competition from other microflora. Nevertheless, B. subtilis is a known stubborn organism that can compete with others in mediating microbial transformations such as those of $\mathrm{S}$ and $\mathrm{P}$ in natural conditions [8].

Figure 2 shows the trend of $\mathrm{P}$ solubilization and phosphatase activity in autoclaved soil amended with $1 \% \mathrm{CP}$ and $10 \% \mathrm{CD}$ in lieu of $B$. subtilis. There was a steady increase in available $\mathrm{P}$ from the 5 th day $(0.77 \mu \mathrm{g} / \mathrm{g}$ soil $)$ to 20 th day $(1.15 \mu \mathrm{g} / \mathrm{g}$ soil $)$ of incubation $[F(1.06,2.12)=111.68$, $p=0.000$, eta $\left.^{2}=0.982\right]$; thereafter, a marginal decrease $(4.34 \%)$ in available phosphate was noticed at the 25 th day. Examination of means suggested that the $\mathrm{P}$ solubilization increased as the incubation period increased up to the 20th day, and the polynomial contrasts indicated that there was a

Fig. 2 Effect of added cow dung (10\%) on P solubilization and phosphatase activity in sterilized Entisol $+1 \% \mathrm{CP}$ : a available phosphate and $\mathrm{pH}$, and $\mathbf{b}$ acid phosphatase and alkaline phosphatase

significant linear trend $[F(1,2)=1,521.33, p=0.001$, eta $\left.^{2}=0.999\right]$. This might be due to metabolism of a part of the available phosphate by $B$. subtilis. Further, there was a $15 \%$ increase in $\mathrm{P}$ solubilization in terms of available $\mathrm{PO}_{4}^{-}$ on the 20th day in CD-amended soil (1.15 $\mu \mathrm{g} / \mathrm{g}$ soil) (Fig. 2) in comparison with soil inoculated with B. subtilis $(1 \mu \mathrm{g} / \mathrm{g}$ soil) (Fig. 1). Similarly, there was a $12.7 \%$ increase in AcP activity in CD-treated soil (230 units) (Fig. 2) over B. subtilis-inoculated soil (204 units) (Fig. 1) after the 20th day of incubation. This presumably might be due to the presence of other microorganisms such as Pseudomonas maltophila, Aspergillus spp., etc. along with $B$. subtilis present in CD [9]. These microorganisms could have performed dual functions: solubilizing inorganic $\mathrm{P}(\mathrm{CP})$ as well as mineralizing organic $\mathrm{P}$, i.e., orthophosphate acid esters (nucleic acid, nucleotides, phospholipids, etc.), present in CD into soluble $\mathrm{P}[10]$. However, there was no significant variation $\left[F(1.15,2.29)=929.60, p=0.000\right.$, eta $\left.^{2}=0.998\right]$ in AlP activity between CD- and $B$. subtilis-treated soil on the same day (20th day) of incubation. Examination of means 
suggested that the AlP activity increased as the incubation period increased. Polynomial contrasts also indicated that there was a significant linear trend between AlP activity and incubation period $[F(1,2)=6,909.43, p=0.000$, eta $\left.^{2}=0.999\right]$.

Table 2 shows the impact of B. subtilis inoculation and CD amendment on phosphatase (acid and alkaline) activity and $\mathrm{P}$ solubilization (available $\mathrm{P}$ ) in rhizosphere and nonrhizosphere samples from cowpea-planted soils. In general, there was higher phosphatase [AcP $(p=0.001$, LSD $=$ 3.86), AlP $(p=0.001$, LSD $=7.91)]$ and $\mathrm{P}$ solubilization $(p=0.001, \mathrm{LSD}=0.042)$ activity in rhizosphere than nonrhizosphere soil. The values obtained (both in rhizosphere and in bulk soil) were higher in variants amended with B. subtilis than in variants amended with $C D$. The results appeared slightly different from data presented in Figs. 1 and 2, in which $\mathrm{P}$ solubilization and AcP activity were found higher in CD-treated soil than in B. subtilistreated soil. This could be due to the two different sets of experimental conditions.

Cowpea plants grown in bacterial-inoculated or CDamended presterilized soil showed a significant increase over those grown in nontreated soil in terms of plant height $(p=0.001, \mathrm{LSD}=1.00)$, root length $(p=0.05, \mathrm{LSD}=$ $3.26)$, and dry matter $(p=0.05$, LSD $=0.32)$ (Table 3$)$. This might have been expected, because the considerable amount of nutrients (N, P, K, etc.) [11] and organic matter present in $\mathrm{CD}$ [5] contribute to greater plant growth. At present, in the Indian Subcontinent, CD, compost, green manure, etc. are usually added to agricultural soils at the rate of 15-20 tons/ha on dry matter basis [assuming soil depth of $15 \mathrm{~cm}$ (for agricultural crops) with $1.2 \mathrm{~g} / \mathrm{cc}$ bulk density] [20, 21]. In the present experiment, CD was applied at $100 \mathrm{~g}$ (fresh weight)/kg soil in polyethylene bags $\left(20 \times 12 \mathrm{~cm}^{2}\right)$, equivalent to 45 tons/ha on dry matter basis. This is admittedly more than double the typical field application rate.

Similar plant growth parameters (biomass) were also obtained with B. subtilis-inoculated soil (Table 3). The increased growth attributes were probably due to synthesis of growth regulators such as indole-3-acetic acid by B. subtilis strain, as evident from our earlier study [23]. Further, in controlled environment such as in autoclaved soil, there could be faster growth of $B$. subtilis because of noncompetence of other microorganisms for utilizing available nutrients in the soil (apart from plants), which could have stimulated greater indole-3-acetic acid production. As a consequence, the effect of single bacterial (B. subtilis) inoculation was found to be on a par with the effect of CD application (Table 3). In our earlier study, B. subtilis CM1 was shown to produce indole-3-acetic acid that enhanced sprouting and root elongation of yam minisetts [23]. Besides, many phosphate-solubilizing bacteria, i.e., Bacillus, Pseudomonas, etc., were reported to enhance plant [mung bean (Vigna radiata L.), cluster bean ( $C y$ amopsis tetragonoloba L.), wheat (Triticum aestivum L.), and chick pea (Cicer arietinum L.)] growth, owing to the production of growth regulators (indole-3-acetic acid and gibberellic acid) coupled with other beneficial activities such as biocontrol and P solubilization [27].

Table 2 Effect of $B$. subtilis CM1 and cow dung (10\%) on phosphatase (units $=1 \mu \mathrm{mol}$ of $p$-nitrophenol/min/ml) and P solubilization activity (available $\mathrm{P}, \mu \mathrm{g} / \mathrm{g}$ soil) in rhizosphere and nonrhizosphere of cowpea-planted presterilized Entisol

\begin{tabular}{|c|c|c|c|c|c|c|c|c|}
\hline & \multicolumn{4}{|c|}{ Rhizosphere } & \multicolumn{4}{|c|}{ Nonrhizosphere } \\
\hline & Soil & $\begin{array}{l}\text { Soil }+ \\
\text { B. subtilis }\end{array}$ & Soil + CD & $\begin{array}{l}\text { LSD } \\
(p=0.05)\end{array}$ & Soil & $\begin{array}{l}\text { Soil }+ \\
\text { B. subtilis }\end{array}$ & Soil + CD & $\begin{array}{l}\text { LSD } \\
(p=0.05)\end{array}$ \\
\hline Acid phosphatase & $108 \pm 5.2$ & $210 \pm 11.2$ & $176 \pm 4.2$ & 3.14 & $88 \pm 4.2$ & $180 \pm 5.1$ & $123 \pm 4.2$ & 4.17 \\
\hline Alkaline phosphatase & $90 \pm 6.4$ & $128 \pm 5.2$ & $122 \pm 2.1$ & 2.47 & $63 \pm 8.2$ & $108 \pm 2.1$ & $98 \pm 5.6$ & 3.02 \\
\hline Available P & $35 \pm 2.0$ & $42 \pm 2.2$ & $40 \pm 3.1$ & 3.23 & $28 \pm 1.8$ & $32 \pm 2.1$ & $38 \pm 2.1$ & 3.96 \\
\hline
\end{tabular}

$n=3 ; \pm$ standard deviation

Table 3 Effect of B. subtilis CM1 and cow dung (10\%) on plant growth parameters of cowpea in presterilized Entisol

\begin{tabular}{lrrrr}
\hline & \multicolumn{1}{c}{ Soil } & Soil + B. subtilis & Soil + CD & LSD $(p=0.05)$ \\
\hline Plant height $(\mathrm{cm})$ & $15.3 \pm 1.2$ & $26.4 \pm 2.0$ & $24.6 \pm 1.6$ & 1.00 \\
Root length $(\mathrm{cm})$ & $12.0 \pm 1.0$ & $19.5 \pm 1.5$ & $19.0 \pm 1.2$ & 3.26 \\
Plant dry weight $(\mathrm{g})$ & $4.7 \pm 0.6$ & $6.8 \pm 1.0$ & $6.0 \pm 0.5$ & 0.32 \\
\hline
\end{tabular}

$n=3 ; \pm$ standard deviation 


\section{Conclusions}

B. subtilis strains isolated from $\mathrm{CD}$ are proven to be a versatile bacteria having manifold beneficial activities such as biocontrol against plant pathogens, production of growth regulator (indole-3-acetic acid) (in our earlier studies), and $\mathrm{P}$ solubilization (as demonstrated in the present study). This bacterial strain is thermotolerant $\left(<50{ }^{\circ} \mathrm{C}\right)$; therefore, in view of global climatic changes, it can be employed as a bio-inoculant in sustainable agricultural systems of the Tropics, where the temperature rises up to $42-45{ }^{\circ} \mathrm{C}$ during summer months (April-June) in countries such as India and Pakistan. Cow dung is traditionally applied in Indian Subcontinental agriculture to enhance soil fertility. In this context, organic farming using natural bioresources such as $\mathrm{CD}$ or an effective multifaceted bio-inoculant such as B. subtilis would not only enhance agricultural productivity but also maintain soil quality. Further research is in progress to validate the P-solubilizing activity of the bacterium in pot culture and field conditions.

Acknowledgments Financial assistance from the Indian Council of Agricultural Research, New Delhi, India [no. 8(39)/2003-Hort.II, dated 7 June 2004] is sincerely acknowledged.

\section{References}

1. Abd-Alla MH, Omar SA (2001) Survival of rhizobia/bradyrhizobia and rock-phosphate-solubilizing fungus Aspergillus niger on various carriers from some agroindustrial wastes and their effects on nodulation and growth of faba bean and soybean. J Plant Nutr 24:261-272

2. Alexander M (1983) Introduction to soil microbiology, 2nd edn. Wiley Eastern, New Delhi, pp 333-349

3. Arcand MM, Schneider KD (2006) Plant and microbial-based mechanisms to improve the agronomic effectiveness of phosphate rock: a review. Anais da Academia Brasileira de Ciências 78:791-807

4. Barroso CB, Pereira GT, Nahas E (2006) Solubilization of $\mathrm{CaHPO}_{4}$ and $\mathrm{AlPO}_{4}$ by Aspergillus niger in culture media with different carbon and nitrogen sources. Braz J Microbiol 37:434 438

5. Bhattacharyya P, Chakrabarti K, Chakraborty A (2005) Microbial biomass and enzyme activities in submerged rice soil amended with municipal solid waste compost and decomposed cow manure. Chemosphere 60:310-318

6. Fioretto A, Fuggi A (2005) Biotechnology of soil enzymes. In: Ray RC (ed) Microbial biotechnology in agriculture and aquaculture, vol 1. Science, New Hampshire, pp 31-70

7. Gupta R, Singh R, Shanker A, Khuad RC, Saxena RK (1994) A modified plate assay for screening phosphate solubilizing microorganism. J Gen Appl Microbiol 40:255-260

8. Hayat R, Ali S, Amara U, Khalid R, Ahmed I (2010) Soil beneficial bacteria and their role in plant growth promotion: a review. Ann Microbiol 60:579-598
9. Kaushik P, Garg VK (2004) Dynamics of biological and chemical parameters during vermicomposting of solid textile mill sludge mixed with cow dung and agricultural residues. Bioresour Technol 94:203-209

10. Kuhad RC, Singh S, Lata, Singh A (2011) Phosphate solubilizing microorganisms. In: Singh A, Parmar N, Kuhad RC (eds) Bioaugmentation, biostimulation and biocontrol, Soil biology series, vol 28. Springer, Heidelberg, pp 65-84

11. Lovell RD, Jarvis SC (1996) Effect of cattle dung on soil microbial biomass $\mathrm{C}$ and $\mathrm{N}$ in a permanent pasture soil. Soil Biol Biochem 28:291-299

12. Macias FA, Marin D, Oliveros-Bastidas A, Varela RM, Simonet AM, Carrera C, Molinillo JMG (2003) Allelopathy as a new strategy for sustainable ecosystems development. Biol Sci Space 17:18-23

13. Mehta S, Nautiyal CS (2001) An efficient method for qualitative screening of phosphate solubilizing bacteria. Curr Microbiol 43:51-56

14. Nautiyal CS (1999) An efficient microbiological growth medium for screening phosphate solubilizing microorganism. FEMS Microbiol Lett 170:265-270

15. Olsen, S.R., Cole, C.V., Watanobe, F.S. \& Dean, L.A. (1954). Estimation of available phosphorus in solid by extraction with sodium bicarbonate. United States Department of Agriculture Circular, Washington, DC 937, p 19

16. Pikovskaya RI (1948) Mobilization of phosphorus in soil in connection with the vital activity of some microbial species. Mikrobiologiya 17:362-370

17. Reyes I, Valery A, Valduz Z (2006) Phosphate-solubilizing microorganisms isolated from rhizospheric and bulk soils of colonizer plants at an abandoned rock phosphate mine. Plant Soil 287:69-75

18. Rodriguez H, Fraga R (1999) Phosphate solubilizing bacteria and their role in plant growth promotion. Biotechnol Adv 17:319-339

19. Ruggiero P, Dar J, Bollag JM (1996) Soil as a catalytic system. In: Strotzky G, Bollag JM (eds) Soil biochemistry, vol 9. Marcel Dekker, New York, pp 79-122

20. Sharma AK (2003) Biofertilizers for sustainable agriculture. Agrobios, India

21. Solaman ARM, Rabbani MG (2006) Effect of NPK and cow dung on growth and yield of tomato. Bull Inst Trop Agric Kyushu Univ 29:31-37

22. Swain MR, Ray RC (2009) Biocontrol and other beneficial activities of Bacillus subtilis isolated from cow dung microflora. Microbiol Res 164:121-130

23. Swain MR, Naskar SK, Ray RC (2007) Indole-3-acetic acid production and effect on sprouting of yam (Dioscorea rotundata L.) minisetts by Bacillus subtilis isolated from culturable cow dung microflora. Pol J Microbiol 56:103-110

24. Tabatabai MA, Bremner JM (1969) Use of $p$-nitrophenyl phosphate for assay of soil phosphatase activity. Soil Biol Biochem 1:301-307

25. Tarafdar JC, Rao AV, Kumar P (1992) Effect of different phosphatase producing fungi on growth and nutrition of mung beans [Vigna radiate (L.) Wilczek] in an arid soil. Biol Fertil Soils 13:35-38

26. Watanabe FS, Olsen SR (1965) Test of an ascorbic acid method for determining phosphorus in water and $\mathrm{NaHCO}_{3}$ extracts from soil. Soil Sci Soc Am Proc 29:677-678

27. Whitelaw MA (2000) Growth promotion of plants inoculated with phosphate solubilizing fungi. Adv Agron 69:99-144 